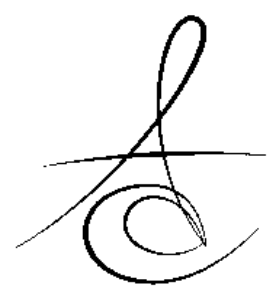

\section{HEMEN İMPLANT YERLEŞTIRIILMESINNDE SOKET ZIRHI UYGULAMASI: VAKA RAPORU}

\section{SOCKET SHIELD TECHNIQUE WITH IMMEDIATE IMPLANT PLACEMENT: A CASE REPORT}

\author{
Dr. Öğr. Üyesi H. Burak KUTLU**
}

Makale Kodu/Article code: 3601

Makale Gönderilme tarihi: 11.03 .2018

Kabul Tarihi: 22.05.2018

\section{öz}

Anterior veya premolar bölgedeki diş kayıplarının implant destekli restorasyonlarında, doğal diş görünümüne benzer görünüm elde etmek için yeterli sert ve yumuşak doku hacmine ihtiyaç duyulmaktadır. Çekim sonrası gerçekleşen demet kemik rezorpsiyonunun sebep olduğu boyutsal değişiklikleri önlemek veya gidermek amacıyla, sert ve yumuşak dokuyu korumaya veya artırmaya yönelik birçok yöntem tanımlanmıştır.

$\mathrm{Bu}$ makalede üst premolar diş eksikliği vakasında, çekim sonrası gerçekleşen alveol kemik rezorpsiyonunu sınırlamak amacıyla bukkal kök parçasının sokette bırakılması prensibine dayanan "soket zırhı" uygulaması ile beraber, aynı seans implant uygulaması sunulmuştur.

Vakanın protetik yükleme sonrası 6 aylık takibinde bölgede herhangi bir inflamasyon bulgusu bulunmaksızın tatmin edici estetiğin elde edildiği görülmüş, soket zırhı yönteminin, estetik gereksinimin yüksek olduğu bölgelerde uygulanabilecek bir tedavi seçeneği olduğu sonucuna ulaşılmıştır.

Anahtar kelimeler: İmplant, soket koruma

\section{ABSTRACT}

To achieve optimal esthetic results with implant rehabilitation of anterior and premolar regions, sufficient amount of bone and soft tissue is requisite. This may be compramised as a result of alveolar bone remodelling following tooth extraction. One of the identified techniques which aim to preserve bundle bone resorption following extraction is "socket shield". The technique is characterized with the retention of buccal fragment of the root in the socket.

In this clinical case report, rehabilitation of an upper premolar tooth deficiency with socket shield technique and immediate implant placement is presented.

After 6 months follow-up, stabilized results without inflammation and with optimal esthetics were achieved. Consequently, socket shield technique may be a reliable technique to perform with simultaneous implant placement in anterior region to obtain esthetic results.

Key words: Implant, socket protection

\section{GíRiş}

Dental implant cerrahisi, yüksek başarı oranı ile diş hekimliğinde güvenilir bir tedavi seçeneği olarak kabul görmektedir. ${ }^{1}$ Gelişen teknoloji ve artan seçenek sayısı ile beraber günümüzde birçok hasta fonksiyonel ve/veya estetik amaçlarla implant tedavisini tercih etmektedir.

'Ağız sağlığı ile ilişkili yaşam kalitesi' kavramı sadece hastalık durumunun veya fonksiyon kaybının etkilerini içermez. Ağız sağlığı, sosyal yaşantı ve kişinin özgüveni gibi psikolojik faktörler üzerinden de yaşam kalitesini etkilemektedir. ${ }^{2}$ Bu nedenle dental estetik gereksinimlerin hayat kalitesindeki önemi büyüktür. Anterior veya premolar diş kayıplarının yarattığı görsel problemin giderilmesi amacıyla dental implantların kullanımı, geçerli ve yaygın bir tedavi seçeneğidir. ${ }^{3}$ Dental implant tedavilerinde estetik sonuçların hasta ile ilgili veya bölgenin anatomisi ile

\footnotetext{
*Serbest Çalışan Diş Hekimi, Periodontoloji Uzmanı

**Hacettepe Üniversitesi Diş Hekimliği Fakültesi Periodontoloji Anabilim Dalı
} 
ilgili pek çok faktörden etkilenmesi sebebiyle ön bölge implantlar, Internaltional Team for Implantology (ITI) tarafindan 'ileri' veya 'kompleks' vakalar olarak tanımlanmaktadır. ${ }^{4}$

Çekim ile aynı seans, hemen implant uygulaması, tedavi sürecini kısaltmak ve çevre dokuları korumak için sıklıkla kullanılmaktadır. Bu uygulamada başarılı sonuçların elde edilebilmesi için uygulama bölgesinde sağlam soket duvarlarının varlığı, en az 1 mm kalınlığında fasiyal kemik duvarı, kalın yumuşak dokunun varlığı, bölgede akut enfeksiyonun yokluğu ve soketin apikalinde/palatinalinde primer stabiliteyi sağlayabilecek kemik varlığı gibi faktörlerin gerekliliğine dikkat çekilmiştir. ${ }^{5}$ Buna rağmen, maksiller kesici dişlerin bukkal duvarının konik ışınlı bilgisayarlı tomografi ile incelendiği çalışmaların sonuçlarına göre, bu dişlerin bukkalinde $1 \mathrm{~mm}$ 'den daha kalın kemik görülme oranı oldukça düşüktür. ${ }^{6-8} \mathrm{El}$ Nahass ve ark. tarafından yapılan çalışmada konik ışınlı bilgisayarı ı tomografi ile üst santral kesicilerin bukkal kemik kalınlıkları alveolar kemik kretinin $0,1,2$ ve 4 . mm'ler seviyesinde incelenmiş, $1 \mathrm{~mm}$ ve daha fazla kalınlıkta kemik görülme oranları sırası ile $\% 1, \% 6, \% 14$ ve $\% 23$ olarak görülmüşsür. ${ }^{6}$

Diş çekimi sonrası dişi çevreleyen demet kemiğin rezorpsiyonu kaçınılmaz bir sonuçtur. Çekim sonrası kemiğin boyutsal değişimlerini değerlendiren 3 , 6 veya 12 ay takipli 12 çalışmayı inceleyen bir metaanalizde, bukkal kemiğin yüksekliğindeki kayıp ortalama $1.67 \mathrm{~mm}$ olarak verilmiştir. Kret genişliğindeki kaybın ise ortalama $3.87 \mathrm{~mm}$ olduğu belirtilmiştir. ${ }^{9}$

Çekim sonrası kret yüksekliği ve genişliğinin koruması için çekim soketine greft, membran, rezorbe olabilen tampon, PRP uygulaması gibi yöntemler kullanılmaktadır. ${ }^{10}$ Bunlara ek olarak kökün sokette bırakılmasının, çekim sonrası oluşan bu fizyolojik değişimleri engelleyebileceği düşünülmektedir. ${ }^{11}$ Daha önce yapılmış pek çok çalışma, kronu uzaklaştııımıı̧ diş köklerinin, vital veya endodontik tedavi sonrası kemik içerisinde bırakılmasının çekim bölgesini koruduğunu göstermiştir. ${ }^{12}$

Hürzeler ve ark. ${ }^{11}$ 'soket zırhı' tekniğini ilk kez tanımladıklarında, çekim sonrası bukkal kemik rezorpsiyonunu engelleyeceği hipotezini kurmuşlardır. Bu amaçla çekim sırasında bukkal bir kök parçası sokette bırakılmakta ve bu kök parçası bukkal kemiği rezorpsiyondan koruyan bir zırh görevi görmektedir. Kökün palatinal kısmının çekim ile aynı seansta bu kök parçasının palatinaline implant yerleştirilmektedir. Konuyla ilgili hayvan modelinde yapılan histolojik çalışma, diş ile temas edecek şekilde yerleştirilen implantı yüzeyinde sement oluştuğunu ortaya koymuştur. ${ }^{11}$ Parlar ve ark. tarafindan, benzer model üzerinden yapılan bir diğer çalş̧ma ise implantlar etrafında fibröz bir kapsül oluştuğunu rapor etmiştir. ${ }^{13}$

İmplantlar kök ile temasta değil, aralıklı yerleştirildiğinde ise periodontal ligament ve sement oluşumu Hürzeller ve ark. tarafından rapor edilmiştir. ${ }^{11}$ Baumer ve ark. tarafindan ise periodontal ligament benzeri bağ dokusu oluşumu rapor edilmiştir. ${ }^{14} \mathrm{Bu}$ iki çalışmada da osseointegrasyonun olumsuz etkilenmemiş olması, tekniğin geçerliliği ile histolojik kanııın mevcudiyetine işaret etmektedir.

$\mathrm{Bu}$ vaka raporunda üst premolar bölgeye uygulanan soket zırhı tekniği ile hemen implant rehabilitasyonu uygulanan bir hasta anlatılacaktır.

\section{VAKA SUNUMU}

45 yaşındaki sistemik olarak sağıılı kadın hasta, kanal tedavili sol üst 1.premolar dişindeki kron/kök kırrğı sebebi ile Hacettepe Üniversitesi Diş Hekimliği Fakültesi'ne başvurdu. Yapılan klinik ve radyografik muayene sonrasında, dişteki madde kaybının fazla olması sebebiyle uygun kron-kök oranına ve protetik retansiyon faktörlerine sahip bir restoratif tedavinin mümkün olmadığı tespit edildi. Söz konusu dişin çekimi ile aynı seans implant uygulaması planlandı. Dişin estetik bölgede yer alıyor oluşu, diş çevresi periodontal dokularda yıkımın bulunmaması, kök ucundaki lezyonun çekim seansında temizlenebilir oluşu nedeniyle ve alveol kemikte oluşacak boyutsal değişiklişin en az düzeyde tutulması amacı ile soket zırhı uygulamasına karar verildi. (Resim 1) Hastaya uygulama ile ayrıntılı ilgili bilgi verildi, yazılı onayı alındı.

Bölgeye lokal anestezi (\%3 articain $\mathrm{HCl}$ ) uygulandıktan sonra diş kökü uca doğru incelen elmas frez yardımı ile bukko-palatinal olarak ikiye ayrılacak şekilde prepare edildi. Palatinal kısım, çevre kemiği koruyarak, dikkatle uzaklaştııılıktan sonra bukkal kısım kök parçası frez ile kemik kretinden $1 \mathrm{~mm}$ koronale uzanacak şekilde, kalkan şeklinde prepare edildi. Kök ucundaki lezyon el aletleri ile temizlendikten sonra, implant preparasyonu yapıldı. Bırakılan köke mine matriks türevi ${ }^{*}$ uygulandıktan sonra implant

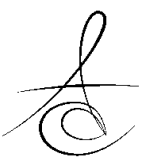


yerleștirildi ${ }^{\ddagger}$. Palatinal bölgedeki soket boşluğu hayvan kaynaklı kemik grefti* ${ }^{* *}$ ile dolduruldu. Dişeti şekillendirici vidalandı, absorbe olabilen jelatin spanç ${ }^{\dagger}$ şekillendirilerek palatinal bölgedeki xenogreftin üzerine kapatıldı. Jelatin spancı bölgeye sabilemek amacıyla 4.0 ipek sutur ile çapraz suturlama yapıldı. (Resim 2) Post-operatif antibiyotik ve analjezik reçete edildi.

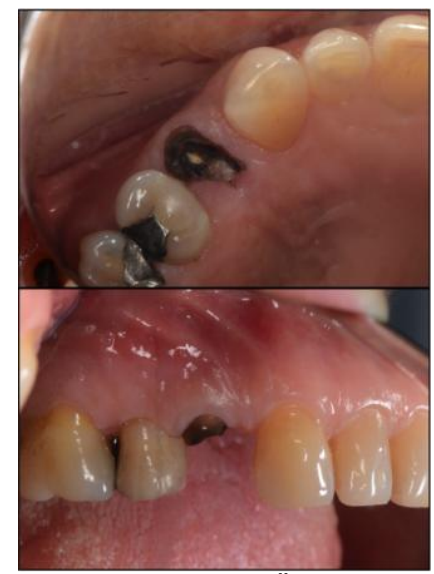

Resim 1. Operasyon Öncesi Klinik Görünüm

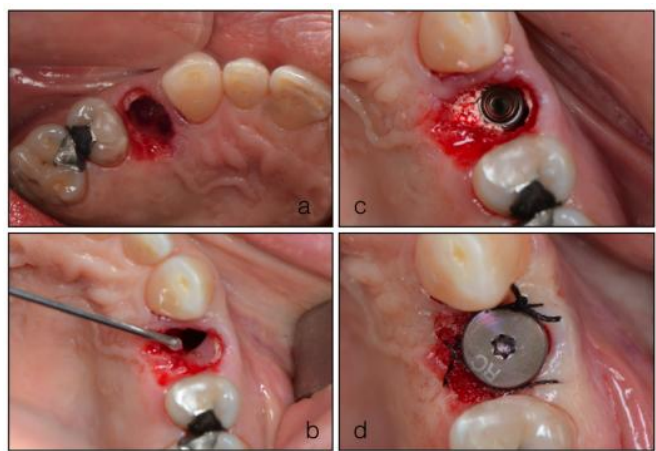

Resim 2. a-Preparasyon ve palatinal parçanın ekstraksiyonu sonrası,

b-Mine matriks türevi uygulaması, c- İmplant-Kök parçası komşuluğu ve greftleme, $d$ - Jelatin spanç yerleştirilmesi ve dikiș

Olaysız gerçekleşen iyileşme sonrasında, dikiş 1. haftanın sonunda alındı. (Resim 3) Yükleme zamanına kadar hasta aylık takibe alındı. Post-operatif 1 . ay kontrolünde bukkal yüzeyde yaklaşı $1 \mathrm{~mm}^{2}$ yüzeyinde diş parçasının dişetini perfore ederek görünür hale geldiği tespit edildi. (Resim 4) Bu parça, lokal anestezi altında, elmas frez yardımıyla uzaklaştırıldı. Sonraki aylarda dişeti bütünlüğünün stabil oluğu gözlendi ve implant 3. ayda protetik olarak yüklendi.

Protetik yükleme sonrası 6 . ay sonunda yapılan muayenede implant çevresinde herhangi bir inflamas- yonun bulunmadığı, implant çevresi cep derinliklerinin her bölgede yaklaşık $3 \mathrm{~mm}$ olduğu ve bukkal konturun korunduğu klinik olarak tespit edildi. Konik Işınlı bilgisayarlı tomografi (KIBT) görüntülemesinde bukkal bölgede, diş-kemik sınırının ayırt edilemediği, implant ile entegre olarak izlenen $2 \mathrm{~mm}$ genişliğinde radyoopak sınırın varlığı incelendi. (Resim 5,6)

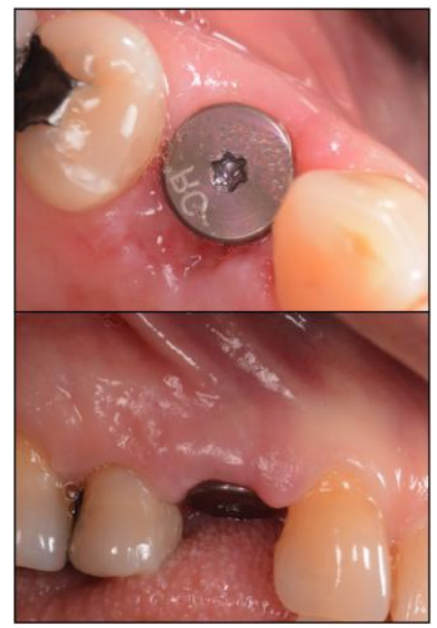

Resim 3. 1. hafta, dikiş alındıktan sonra

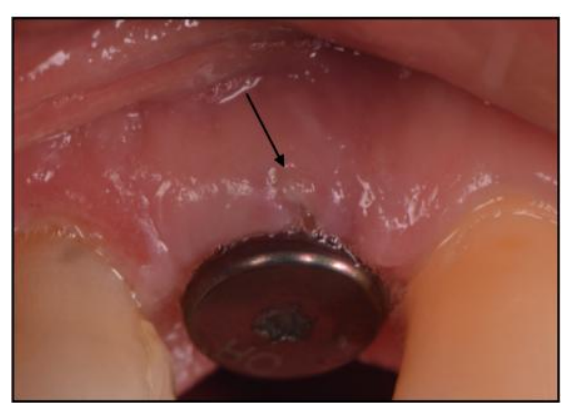

Resim 4. 1. ay sonu-Bukkalde görünen kök parçası

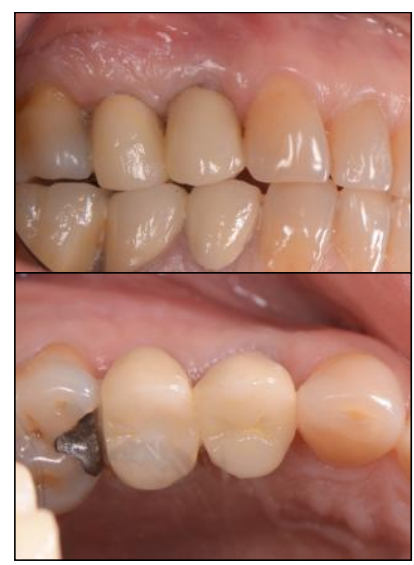

Resim 5. Daimi restorasyon simante edildikten 6 ay sonra

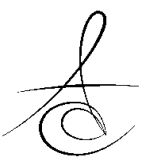




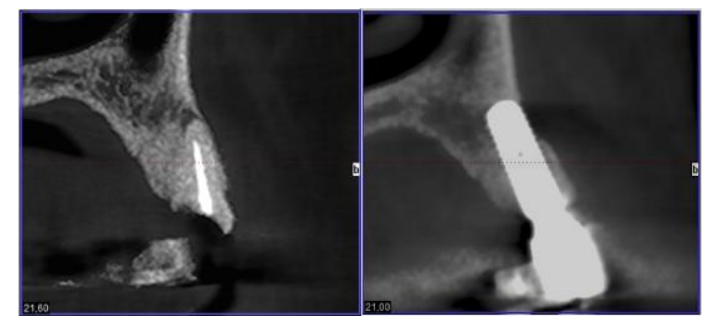

Resim 6. İşlem öncesi ve sonrası konik ışınlı bilgisayarlı tomografi (KIBT) görüntüsü karşılaştırması- Operasyon öncesi dişin bukkalindeki kemiğin $1 \mathrm{~mm}$ 'den ince olduğu görülmekteyken, implant rehabilitasyonu sonrası kök parçasının bulunduğu bukkal bölgede implant ile temasta, 1 mm'den kalın yoğun radyoopak görünüm ${ }^{*}$ Straumann $^{\circledR}$ Emdogain $^{\mathrm{TM}}$ (Malmö, İsvec)

${ }^{\ddagger}$ Straumann ${ }^{\circledR}$ Bone Level RC (4.1X12) (Villeret, İsviçre)

${ }^{* *}$ Botiss Cerabone ${ }^{\circledR}$ (Zossen, Almanya)

${ }^{\dagger}$ TechNew Hemospon ${ }^{\circledR}$ (Taoyuan City, Tayvan)

\section{TARTIȘMA VE SONUC}

Diş çekimi ve sebep olduğu travma, bukkal soket duvarının rezorpsiyonuna neden olmaktadır. ${ }^{15}$ Tedavi süresini kısaltmak ve 6 aydan uzun süren dişsizliğin kemik hacmi üzerindeki olumsuz etkisini önlemek amacıyla gerçekleştirilen, çekimin yapıldığı seans hemen implant uygulaması gerekli osseointegrasyonu sağlamakta, fakat bu uygulamanın çekim soketinin erken dönem biyolojik cevabına etkisi bulunmamaktadır. ${ }^{16}$ Köklerin bırakılarak alveolar şekillenmeden kaçınııması uzun zaman önce tanımlanmış bir tekniktir ${ }^{17}$ ve dental travmatolojide kullanılmaktadır. Periodontal ligamentin bulunduğu bölgede demet kemiğin korunması prensibine dayanan bu teknik, implantolojiye uyarlanmış, bukkal bölgedeki periodontal ligamenti koruyarak yerleştirilen implantlarda, bukkal kemik rezorpsiyonunun önleneceği hipotezi, uygulamanın temelini oluşturmuştur.

İlk defa Hürzeler ve ark. ${ }^{11}$ tarafından "soket zırhı" olarak adlandırılan, kökün bukkal kısmını sokette bırakma tekniği ile ilgili tek vaka-kontrol çalışması Abadzhiev ve ark. ${ }^{18}$ tarafından yapılımışıı. Bu çalışmada 24 aylık takip sonucu soket kabuğu grubunda daha az kemik kaybı, estetik ve yumuşak doku hacmi açısından daha iyi sonuçlar bulunmuştur.

Hürzeler ve ark. ${ }^{10}$ tarafından yapılan çalış̧mada, histolojik incelemede kökün iç yüzeyinin yeni sement ve periodontal ligament ile kaplanmış olduğu görülmüştür. Yazarlar bu durumun mine matriks türevinin kullanımı ile açıklanabileceği yorumunda bulunmuştur.
Mine matriks türevleri periodontal doku- ların rejenerasyonunda rol oynamaktadır. ${ }^{19}$ Ayrica mine matriks türevlerinin epitel dokusunun proliferasyonunu engellediği ve antimikrobiyal kapasitesi olduğu belirtilmiştir. $^{20}$ Bu özelliklerinden dolayı vakamızda mine matriks türevi kullanılmıştır.

Vakamızda 1. ay sonunda, inflamasyon olmaksızın bukkalde görünür hale gelen kök parçası, kökün tamamı alınmaksızın frez ile lokalize olarak uzaklaştırımıştır. Devam eden aylardaki takiplerinde bukkal dişeti bütünlüğünü bozan başka bir duruma rastlanmamıştır. Daha önce buna benzer şekilde, Cherel ve ark. ${ }^{21}$ tarafından gerçekleştirilen soket zırhı uygulamasında, geçici protez çıkarıldığında görünür hale gelen kök parçasının varlığı rapor edilmiştir. Parça hareketsiz olduğundan herhangi bir müdehalede bulunulmadığı ve bu vakanın 1. yıl takibi sonunda olumsuz bir durum gözlenmediği rapor edilmiş̧ir. Diş parçasının görünür hale gelişi, zırhın şekillendirilmesi sırasında, söz konusu koronal kössenin frezle yeterince yuvarlaklaştırımaması ve kalan sivri köşenin dişetini perfore etmesi sonucu gerçekleşmiş olabilir.

Kökün bukkal kısmının retansiyonu ile hemen implant uygulaması estetik bölgelerde uygulanabilecek bir yöntemdir. Henüz kanıta dayalı bir yöntem değilse de umut vaadeden bir tedavi seçeneğidir. Gelecekte, uzun dönem takipli klinik çalışmalara ve histolojik kanıtlara ihtiyaç bulunmaktadır.

\section{TEŞEKKÜR}

Vakanın fotoğraflanmasında emeği geçen Uzm. Dt. Birtan Tolga Yılmaz'a ve Uzm. Dt. Elnur Comerdov'a teşekkürlerimi sunarım.

Nil Yakar: ORCID ID:: 0000-0002-0568-0928

Burak Kutlu: ORCID ID:: 0000-0002-7323-5615

\section{KAYNAKLAR}

1. Gotfredsen K. A 10-year prospective study of single tooth implants placed in the anterior maxilla. Clin Implant Dent Related Res2012;14:80-7.

2. Klages U, Bruckner A, Zentner A. Dental aesthetics, self-awareness, and oral health-related quality of life in young adults. Eur J Orthod 2004; 26: 507-14.

3. Chen ST, Buser D. Esthetic outcomes following immediate and early implant placement in the anterior maxilla--a systematic review. Int J Oral \& Maxillofac Imp 2014;29 Suppl:186-215.

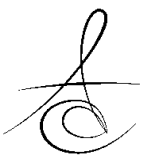


4. Dawson A, Chen S, Buser D, Cordaro L, Martin W, Belser $U$. The SAC classification in implant dentistry: Quintessenz Verlag 2010.

5. Morton D, Chen ST, Martin WC, Levine RA, Buser D. Consensus statements and recommended clinical procedures regarding optimizing esthetic outcomes in implant dentistry. Int J Oral \& Maxillofac Imp 2014;29:216-20.

6. El Nahass $\mathrm{H}, \mathrm{N}$ Naiem $\mathrm{S}$. Analysis of the dimensions of the labial bone wall in the anterior maxilla: a cone-beam computed tomography study. Clin Oral Implants Res 2015;26.

7. Januário $A L$, Duarte $W R$, Barriviera $M$, Mesti JC, Araújo MG, Lindhe J. Dimension of the facial bone wall in the anterior maxilla: a cone-beam computed tomography study. Clin Oral Implants Res 2011;22:1168-71.

8. Nowzari H, Molayem S, Chiu CHK, Rich SK. Cone beam computed tomographic measurement of maxillary central incisors to determine prevalence of facial alveolar bone width $\geq 2 \mathrm{~mm}$. Clin Implant Dent Related Res 2012;14:595-602.

9. Van der Weijden F, Dell'Acqua F, Slot DE. Alveolar bone dimensional changes of post-extraction sockets in humans: a systematic review. J Clin Periodontol 2009;36:1048-58.

10. Çakir M, Karaca İR. İmplant uygulamalari için kret koruma teknikleri. Atatürk Üniv Diş Hek Fak Derg 2015;25.

11. Hürzeler MB, Zuhr O, Schupbach $P$, Rebele SF, Emmanouilidis $\mathrm{N}$, Fickl $\mathrm{S}$. The socket-shield technique: a proof-of-principle report. J Clin Periodontol 2010;37:855-62.

12. Filippi A, Pohl Y, Von Arx T. Decoronation of an ankylosed tooth for preservation of alveolar bone prior to implant placement. Dent Traumatol 2001;17:93-5.

13. Parlar A, Bosshardt DD, Ünsal B, Çetiner D, Haytaç C, Lang NP. New formation of periodontal tissues around titanium implants in a novel dentin chamber model. Clin Oral Implants Res 2005; 16:259-67.

14. Bäumer D, Zuhr O, Rebele S, Schneider D, Schupbach $P$, Hürzeler $M$. The socket-shield technique: first histological, clinical, and volumetrical observations after separation of the buccal tooth segment-a pilot study. Clin Implant Dent Related Res 2015;17:71-82.
15. Schropp L, Wenzel A, Kostopoulos L, Karring T. Bone healing and soft tissue contour changes following single-tooth extraction: a clinical and radiographic 12-month prospective study. Int J Periodont \& Rest Dent 2003;23.

16. Vignoletti $F$, De Sanctis $M$, Berglundh $T$, Abrahamsson I, Sanz M. Early healing of implants placed into fresh extraction sockets: an experimental study in the beagle dog. II: ridge alterations. J Clin Periodontol 2009; 36: 688-97.

17. Malmgren B, Cvek M, Lundberg M, Frykholm A. Surgical treatment of ankylosed and infrapositioned reimplanted incisors in adolescents. Eur J Oral Sci 1984; 92: 391-9.

18. Abadzhiev MN PV. Conventional immediate implant placement and immediate placement with socketshield technique - Which is better. Int J Clin Med Res 2014;1:176-80.

19. Sculean A, Chiantella GC, Windisch P, Donos N. Clinical and histologic evaluation of human Intrabony defects treated with an enamel matrix protein derivative (Emdogain). Int J Periodont \& Rest Dent 2000; 20: 334-5.

20. Bosshardt DD. Biological mediators and periodontal regeneration: a review of enamel matrix proteins at the cellular and molecular levels. J Clin Periodontol 2008;35:87-105.

21. Cherel F, Etienne D. Papilla preservation between two implants: a modified socket-shield technique to maintain the scalloped anatomy? A case report. Quintessence Int 2014;45: 23-30.

\author{
Yazışma Adresi \\ Uzm. Dt. Nil YAKAR \\ Gençlik cad. 57/6 Anıttepe \\ e-mail: nilykr@gmail.com \\ nilykr@gmail.com
}

